\title{
External Debt and Economic Growth in Nigeria
}

\author{
1. OBAYORI, Joseph Bidemi,2. KROKEYI, Wisdom Selekekeme, 3. KAKAIN, Stephen \\ 1. Department of Economics, Faculty of Social Sciences, NnamdiAzikiwe University, Awka, Nigeria \\ 2. Department of Economics, Niger Delta University, Wilberforce Island, Bayelsa State, Nigeria \\ 3. Department of Agriculture and Applied Economics, Rivers State University, Port Harcourt, Nigeria
}

\begin{abstract}
External credits have been received from various sources including bilateral and multilateral arrangements but the country's debt is a source of worry since the projects for which these loans were contracted cannot finance the credit facilities. This paper focused on the impact of external debt on economic growth in Nigeria within the period of 1980 to 2016. Thus, secondary data on gross domestic product and external debt were sourced from CBN statistical bulletin and debt management office fact book. The econometric method of Generalized Method of Moments(GMM) test was used. Priori the GMM test is the Kwiatkowski, Phillips, Schemidt and Shin, (KPSS) unit root test to ascertain the stationarity of the variables. Based on the empirical results; the KPSS stationarity test for each of the series showed that all the variables were stationary at order one as their respective LM statistics was less than the critical value at 5\%. The GMM test shows that external debt and economic growth has positive and significant relationship with $R^{2}$ of 54 percent. Therefore, to achieve long-term solution to the problem of external debts burden, government should stimulate domestic production to liberate the Nigerian economy from the shackles of wants and excessive dependence on external economics, which build up debt. Also, government should avoid unnecessary and unproductive borrowing that will serve as a leakage to the economy. This to a large extent will enhance the growth of the Nigerian economy.
\end{abstract}

KEY WORDS:GDP, GMM, KPSS, External Debt, External Debt Service, Economic Growth

\section{INTRODUCTION}

Nigeria is the world's seventh-largest oil exporter but also one of the poorest developing countries, characterized by inadequate internal capital formation arising from the vicious circle of low productive, low income and low savings. Her internal generated revenue and other sources of public finance are not adequate to sustain the growth and development of her citizenry (Gbosi, 2015). Thus, the need to resort into international communities for external borrowing (external debt) in order to improve the standard of living of her citizen. Thus, external borrowing serves as that part of a country's debt that was borrowed from foreign lenders including commercial banks, governments or international financial institutions in order to increase economic growth.Economic growth on the other hand is the increase in the amount of the goods and services produced by an economy over time.

One of the reason for external borrowing is that the terms of foreign borrowings are often more favourable than for domestic borrowing. This is because the rate of interest as well as the period of maturity of the former is more favourable than the later. But one weakness to foreign borrowing is currency risk, which may increase along with foreign indebtedness, given that a growing foreign debt service increases the demand for foreign exchange.

The antiquity of Nigeria external debt dates back to 1958 when the sum of \$28 million was contracted for rail way construction. Between1958 and1977,the level off foreign debt was minimal; as debt contracted during the period were the conventional debt from bilateral and multilateral sources with longer repayment periods and lower interest rates. During this period, the oil price was high and paying debt service was no problem(Ijeoma, 2013). But since the falls in internal oil prices in 1978, Nigeria government has resorted to borrowing through internal and external sources to drive the economy.

According to Eyiuche(2003), 91.4\%ofthe debt came from loans from bilateral and multilateral agencies. Thus, the first major federal government external borrowing of US\$1 billion from the international capital market 
(ICM) was referred to as "Jumbo loan" increasing her total external debt to $\$ 22$ billion. But it is pertinent to note that the sharp increase in the Nigerian external debt stock after the collapse of oil prices in 1978 was attributable mainly to the inability of the economy to promote export of finished goods as well as inability of government to embark on necessary adjustment, particularly at the time of declining revenue that resulted in growing fiscal deficits and promote external debt accumulation (Gbosi, 2015).

Meanwhile, one of the major problems that have hindered the attainment of sustainable growth has been excessive reliance by the federal government on external borrowing from the banking system, particularly the World Bank and international monetary fund, to finance its large and unsustainable fiscal deficits. Such borrowings from the World Bank and other financial institution amounts to the injection of high powered money into the system, which has serious adverse implication on price and exchange rate stability.

Accordingly, between 1985 and 2001 Debt Management Office showed that thirty two billion dollars was spent for servicing debtin Nigeria (DMO, 2006). Apparently, greater revenue of the country was devoted in servicing her debt thus playing down investment capital and economic growth in the country. However, Nigeria had a debt relief from Paris Club that saved the country from the yearly $\$ 2.3$ billion the government transferred to service its debt. Itwas proposed that this amount will then be available to be ploughed back and channeled to those areas that concern wealth creation, employment generation, agriculture, health, education, water supply, power generation and road construction. The country is therefore expected to be on the path of economic recovery characterized by greater budgeting allocation to key sectors such as power, healthandeducation in order toimproved living standard.But the reverse was the case.

According to Soludo (2003), prior to the debt relief, the country was on the wrong side of the debt-laffer-curve, with debt crowding out investment and growth. After the relief, what could still be crowding out investment and growth in Nigeria as the Human Development Index (HDI)as reported by United Nations Development Programme (UNDP) in 2011 ranked Nigeria 156 out of 187 countries of the world in terms of her level of income and economic growth with a HDI of 0.429 in 2005,0.45in2010 and 0.459 in 2011.

In lieu of the above stated problems, it could be affirms that sluggish growth and external debt services could be caused by external debt stock. The above state of affair raises this question; what is the impact of external debt on economic growth in Nigeria? It is the answer to this question that motivated this work. This paper is structured into five sections. Section one is the introduction, section two is the literature review, section three is the research method, section four is the results and discussions and section five is the conclusion and recommendations.

\section{LITERATURE REVIEW}

Literature review in terms of external debt and economic growth was considered under theoretical literature and empirical literature reviewed.

\section{Theoretical Literature}

Theoretically, the research was based on debt overhangand liquidity constraint hypotheses.According to Krugman (1988), debt overhangs and the 'liquidity constraint hypothesesisa situation where a country's debt service burden is huge that a large proportion of output accrues to foreign lenders creates disincentive to invest. Debt overhang concept is on the premise that in the nearest future; debt will exceed the country's repayment ability. Thus, the expected debt service will be an aggregate function of the output of economy (Claessens, 1996). Similarly, in relation to this theory, Elbadawi, Ndulu andNdung'u(1996) postulates that debt reduction will lead to increased investment and repayment capacity and, invariable give room for repayment of outstanding debt. The effect gives rise to what is known as "Laffer Curve". Thus, debt Laffer curve is the relationship between the amount of debt repayment and the size of debt. Given the debt Laffer curve, Lensink and White (1999) argued that there is a threshold at which more debt is detrimental to growth.

On the other hand, the liquidity constraint postulates that debt serviceis a negative function for funds available for investment and growth. Thus, any decrease in the current debt service will lead to an increase in current investment for any given level of future indebtedness (Cohen, 1993). 


\section{Empirical Literature}

Most empirical studies that examined the impact of external debt on economic growth in the developing economies include the work of Iyoha (1999) who used simultaneous approach to investigate the impact of external debt on economic growth in sub-Saharan African nations using a small macroeconomic model estimated for 1970-1994. The finding revealed that external debt has indirect effect on investment. Thus, reduction in debt stock will positively increase investment and economic growth. Ogunmuyiwa (2011) examined the tendency of external debt to promote economic growth in Nigeria with granger causality test. The author finds out that there is no causal relationship[ between external debt and economic growth.

Sulaiman and Azeez (2012) used ECM to examine the effect of external debt on economic growth of Nigeria. The finding from the error correction method shows that external debt has contributed positively to the Nigerian economy.Ayadi and Ayadi (2008) used GLS model to find out the link between external debt and economic growth in Nigeria and South Africa. They found that there is an indirect relationship between debt, debt service and economic growth in Nigeria and South Africa.

Udeh, Ugwu and Onwunka (2016) examined the impact of external debt on economic growth in Nigeria. The estimated model was analyzed using Ordinary Least Square and Error Correction Mechanism. The findings showed that external debt had a positive relationship with gross domestic product at short run, but a negative relationship at long run.Kasidi and Said (2013) used granger causality test to investigate the effect of external debt an economic of growth in Tanzania using time series of 1990-2010. The study revealed that when external debt stock has a positive effect on economic growth, debt service payment has a negative effect on economic growth. Bamidele and Joseph (2013) examined the effect of financial crisis, external debt management on the economic growth of Nigeria with the use of OLS. The result showed a direct relationship between FDI and economic growth while indirect relationship existed between external debt and economic growth.

Ekperiware and Oladeji(2012) examined the relationship between external debt and economic growth in Nigeria from 1980-2009 with the use of chow test technique of estimation to determine the structural break effect of Paris Club debt relief. The result showed that debt relief triggered growth in the Nigerian economy

\section{RESEARCH METHOD}

The study used secondary data collected from CBN statistical bulletin (2016) and applied the KPSS unit root test, GMM test and the normality test to examine the impact of external debt on economic growth.

\section{Theoretical Framework}

Theoretically, the study was based on debt overhangs and the 'liquidity constraint hypotheses. Debt overhang hypothesis premised that if debt will exceed a nation repayment ability, expected debt service is an increasing function of output level.Similarly, the liquidity constraintposited that debt service reduces funds available for investment and growth. Thus, output is a negative function of debt service. The theory is functionally stated as $Q=f(D)$

Where; Q is output and D is debt service.

The model of the study posited that a well utilize debt will bring about economic growth. Thus, the model is stated in a log-linear for as;

$\mathrm{LnGDP}=\operatorname{Ln} \alpha_{0}+\alpha_{1} \operatorname{LnED}_{\mathrm{t}}+\mathrm{U}_{\mathrm{t}}$

Where; GDP=Gross Domestic Product (Economic Growth), ED=External Debt Stock, Ln = Natural Logarithm, U = Error Term, $\mathrm{t}=$ Time/Period, $\alpha_{1}=$ Slope Parameter and $\alpha_{0}=$ Intercept Parameter. On the apriori, it is expected $\alpha_{1}>0$

\section{Pre- Estimation Tests}

\section{The Unit Root Test}

The unit root test via the Kwiatkowski, Phillips, Schemidt and Shin (KPSS) test of stationarity of the variables precedes the GMM test. The KPSS has advantage of associating with low power in the evident of structural break in the series. The null hypothesis of stationarity is tested against the alternative hypothesis of no stationarity at 5 percent level. This general form of the unit root test model with a constant and trend is formalized below: 


\section{The Generalized Method of Moments(GMM)}

The GMM estimation technique is preferred in the study due to its ability to produce unbiased estimators even with lagged dependent variables acting as instruments. It is capable of avoiding biased results due to correlation between the error term and the lagged endogenous variable. Therefore, given the order of integrationof GDP and ED. The following GMM model was formulated to ascertain the relationship between external debt and economic growth in Nigeria

The equation of the GMM is given as $\sum\left(\mathrm{z}\left(\mathrm{y}_{1}-\mathrm{x}_{1} \beta\right)=0\right.$

By substitution into the model in equation (3.2);

$\mathrm{LnGDP}_{\mathrm{t}}=\alpha_{\mathrm{o}}+\alpha_{1} \mathrm{ED}_{\mathrm{t}}+\mathrm{U}$

Where; $\alpha_{\mathrm{o}}$ is the constant term, $\mathrm{GDP}_{\mathrm{t}-1}$ is one year past value of economic growth, $\mathrm{U}$ is the error term at time and $\mathrm{ED}_{\mathrm{t}}$ is external debt at current form.

\section{Post Estimation Test}

Here the normality test was used to affirms the reality of the GMM test. This was done with the view to ascertain the normal distribution of the residual. The probability value of the Jarque-Bera statistics forms basis for rejecting the null hypothesis.

\section{RESULTS AND DISCUSSIONS}

The study examined external debt and economic growth in Nigeria during the period 1980-2016. An econometric model was constructed for the growth of the Nigerian economy. The constructed model has gross domestic product (GDP) as the dependent variable while external debt (ED) is the independent variable. The variables were measured in Nigeria currency. The various regression results were presented and discussed in the tables below;

Table1: Unit Root Test of Stationarity

\begin{tabular}{l|l|l|l|l|l|}
\hline Series & Levels test & \\
\hline \multicolumn{7}{c}{ LM Stat. } & Critical value (5\%) & LM stat. & Critical value (5\%) & Order of integration \\
\hline LOG(GDP) & 0.7277 & 0.4630 & 0.2496 & 0.7390 & I(1) \\
\hline LOG(ED) & 0.550 & 0.4630 & & & I(1) \\
\hline
\end{tabular}

Source: Author's Computation from (E- view 9.0)

The result of the KPSS stationarity test of each of the series is presented in Table 1illustrated that none of the variables was stationary at levels. This is because the LM statistics for each of the values at the levels test are higher than 5 percent critical value (0.4630). This implies that the series have unit root or are non-stationary. This finding could be attributed the common properties of time series variables which often depict a unit root process. The variables were then differenced once to attain stationarity. The result showed that the variableswere stationary at first difference as their respective LM statistics are less than 5 percent critical values. 
Table 2: Generalized Method of Moments Result

\begin{tabular}{|c|c|c|c|c|}
\hline \multicolumn{5}{|c|}{ Dependent Variable: LOG(GDP) } \\
\hline \multicolumn{4}{|c|}{ Method: Generalized Method of Moments } & \multirow[b]{2}{*}{ Prob. } \\
\hline Variable & Coefficient & Std. Error & t-Statistic & \\
\hline $\mathrm{C}$ & 10.09269 & 0.631720 & 15.97653 & 0.0000 \\
\hline LOG(ED) & 0.212080 & 0.053106 & 3.993492 & 0.0003 \\
\hline R-squared & 0.543769 & Mean dependent $\mathrm{v}$ & & 12.77303 \\
\hline Adjusted R-squared & 0.496527 & S.D. dependent var & & 0.686983 \\
\hline Durbin-Watson stat & 1.940508 & J-statistic & & $4.76 \mathrm{E}-44$ \\
\hline
\end{tabular}

Source: Authors' Computation from (E-view 9.0).

The estimated GMM regression result showed that coefficient of external debt appeared with positive sign and statistically significant at $5 \%$ level. Thus, a percentage increase in external debt will increase economic growth by $0.21208 \%$. Also, the t-statistic of 3.993 with the t-prob of 0.0003 shows that there is a significant relationship between external debt and economic growth in Nigeria during the period of study. Thus, the alternative hypothesis was accepted. The $\mathrm{R}^{2}$ of 0.54 shows that $54 \%$ systematic variation of the dependent variable was caused by the independent variable (external debt). This shows the good fit of the model. Also, the Durbin Watson of 1.94 shows the presence serial autocorrelation is not a problem in the model. Thus, the estimated model is fit for police formulation and implementation.

Table 3: Post Estimation Test (Normality Test)

\begin{tabular}{|l|l|l|l|}
\hline Test type & Test stat. & p-value & $\begin{array}{l}\text { Critical Value @ } \\
\mathbf{5 \%}\end{array}$ \\
\hline Normality test & Jarque-Bera statistics & 0.8254 & 0.05 \\
\hline
\end{tabular}

Source: Authors' Computation from (E- view 9.0).

The post-estimation test result as reported in Table 3 disclosed that the residuals are normally distributed as the Pvalue $0.8254>0.05$. Thus, the normality test is very welcoming as it indicates that the model is associated with a constant residual variance and normally distributed errors. Thus, the estimated parameters are stable over time and as such can produce a reliable forecast.

\section{CONCLUSION AND RECOMMENDATIONS}

This paper examined the impact of external debt on economic growth in Nigeria within the period under 1980-2016. The paper fond that external credits have been received from both bilateral and multilateral arrangements but the country's debt is a source of worry since the projects for which these loans were contracted cannot finance the credit facilities.Added to this, are interrelated factors such as the declining exchanges receipts due to fall in oil price, ineffective domestic economic policy measures amongst others. The implication of all these is that the huge debts and their service payments became problematic to the country's economic growth.

Based on empirical results; the KPSS stationarytestshowed that all the variables are stationary and the GMM result showed that external debt and economic growth were positively and significantly related. The post-estimation test result shows that the estimated parameters are stable over time and as such can produce a reliable forecast.Therefore, to check the plague of external debts, Nigeria needs changes in her economic production structure and consumption patterns. Also, to achieve long-term solution to the problem of external debts burden, there is the need to promote 
International Journal of Science and Management Studies (IJSMS)

Volume: 02 Issue: 02
E-ISSN: 2581-5946

www.ijsmsjournal.org

the country's export trade by stimulating domestic production. This will increase domestic productivity in all sectors of the economy and ensure self-radiant and possible debt free economy.

\section{REFERENCES}

[1] Ayadi, F.S. \&Ayadi, F.O (2008). The Impact of External Debt on Economic Growth: A Comparative Study of Nigeria and South Africa. Journal Sustainable Development in Africa. 10 (3).

[2] Bamidele, T. B. \& Joseph, A. I. (2013). Financial Crisis and External Debt Management in Book Nigeria Ltd. Central Bankof Nigeria(2016).AnnualReport and StatementofAccounts

[3] Claessens, S. (1996). The debt LafferCurve: Some Empirical Estimates. World Dev. 18(12),38-45.

[4] Cohen, D. (1993). Low Investment and Large LCD Debt in the 1980's.The American Economic Review.18 (3).

[5] Debt Management Office of Nigeria (DMO) 2006.www.dmo.gov.ng

[6] Ekperiware, M.C. \&Oladeji, S.I. (2012).External Debt Relief and Economic Growth in Nigeria.American Journal of Economics.2(7).

[7] Elbadawi, A. I., Ndulu, J. B. \&Ndung'u, N. (1996).Debt Overhand and Economic Growth in Sub-Saharan Africa. A Paper Presented at the MF/World Bank Conference on External.

[8] Eyiuche,A.C.(2003).TheoryandMethodologyofDevelopmentDevelopingCountries:NigeriaPlanningExperience1945-2000. Enugu Maurice Production Services.

[9] Gbosi, A.N. (2015). Contemporary Macroeconomic Problems and Stabilization Policies (2 ${ }^{\text {nd }}$ Edition). Benin City: Spirit and Truth Publishers.

[10] Ijeoma, N. B. (2013). An EmpiricalAnalysisof the ImpactofDebt on theNigerian Economy.AnInternationalJournalof ArtsandHumanities. 2(3), 165-191.

[11] Iyoha, M.A. (1999). An Economic Study of Debt Overhang, Debt Reduction, Investment and Economic Growth in Nigeria".NCEMA Monograph Series, No. 8.

[12] Kasidi, F. \& Said, A. M. (2013). Impact of External Debt on Economic Growth: A Case Study of Tanzania,Advances in Management and Applied Economics, 3(4), 59 - 82.

[13] Krugman, P.R. (1988). Financing Versus Forgiving a Debt Overhang.Journal of Development Economics.29, 253-268

[14] Lensink, R, \& White, H. (1999). Is there an aid Laffer curve? Credit Research Paper No. 99/6. Nottingham: Centre for Research in Economic Development and International Trade, University of Nottingham.

[15] Ogunmuyiwa, M.S. (2011). Does External Debt Promote Economic Growth? Current Research Journal of Economic Theory.3(1), 29-35

[16] Soludo, C.C. (2003). Debt Poverty and Inequality in OkonjoIweala, Soludo, and Muntar (Eds), the Debt Trap in Nigeria. Africa World Press NJ, pp. 23-74

[17] Sulaiman, L.A. \&Azeez, B.A. (2012).Effect of External Debt on Economic Growth of Nigeria.Journal of Economic and Sustainable Development.3(8), 71-79

[18] Udeh, S. N., Ugwu, J.I. \&Onwuka, I.O. (2016).External Debt and Economic Growth: The Nigeria Experience. European Journal of Accounting Auditing and Finance Research. 4(2), 33-48

[19] UNDP (2011).United NationsDevelopmentProgrammeReport on Financing for Low Income Countries in Washington DC. 